Guest Editorial, part of a Special Feature on Scenarios of global ecosystem services

\title{
Editorial: Special Feature on Scenarios for Ecosystem Services
}

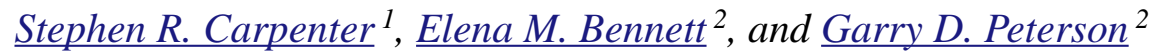

Key Words: adaptive governance; ambiguity; ecological change; ecosystem services; poverty reduction; regime shift; resilience; scenarios.

The Millennium Ecosystem Assessment (MA, http ://www.MAweb.org) was the first global assessment of ecosystem services. The purpose of an assessment is to synthesize peer-reviewed scientific information in a form that is relevant to policy, but does not prescribe policy. The overarching goals of the MA were to synthesize information about the status, trends, and plausible futures of ecosystem services, as well as the policy instruments available for governing or managing ecosystem services.

Ecosystem services are the benefits that people obtain from nature (MA 2003). The MA organized ecosystem services into four categories: "provisioning services," such as food, water, and forest products; "regulating services," which affect climate, floods, disease, wastes, and water quality; "cultural services," which provide recreational, aesthetic, and spiritual benefits; and "supporting services," such as soil formation, photosynthesis, and nutrient cycling.

The MA conceptual framework (MA 2003) considered feedbacks at multiple scales among indirect drivers, direct drivers, ecosystem services, and human well-being (Fig. 1). Direct drivers are human actions and natural processes that directly alter flows of ecosystem services. Ecosystem services, defined above, affect human well-being, including livelihoods, health, and security. Human well-being has complex reciprocal feedbacks with indirect drivers, the social processes that influence direct drivers of ecosystem services. The MA scenarios considered the full set of feedbacks depicted in Fig. 1 at a global scale, and at sub-global scales for some selected cases.
The MA was called for by the United Nations Secretary General, Kofi Annan, in 2000. Governments subsequently supported the establishment of the assessment through decisions of international conventions (Convention on Biological Diversity, United Nations Convention to Combat Desertification, Ramsar Convention on Wetlands, and the Convention on Migratory Species), and established the MA in 2001. From 2001 to 2005, the MA assessed the consequences of ecosystem change for human well-being, and the scientific basis for actions needed to enhance the conservation and sustainable use of ecosystems and their services. The MA was conducted by about 1360 experts from 95 countries in four working groups. In addition, an independent peer-review process involved about 900 experts. One working group addressed ecosystem services in selected regions of the world (Sub-global Working Group, MA 2005a), and the other three working groups addressed global patterns: Conditions and Trends in Ecosystem Services (MA 2005b), Scenarios for Future Ecosystem Services (MA 2005c), and Policy Response Options (MA 2005d). This Special Feature presents key findings of the Scenarios Working Group, drawing some supporting information from the reports of the other working groups.

We begin the special feature with an overview paper that explains some of the problems of addressing ecosystem services that were not addressed by previous global scenarios, as well as some crosscutting findings from the MA scenarios (Carpenter et al. 2006). The next paper presents a synthesis of the qualitative storylines (Cork et al. 2006). Some key aspects of the scenarios that could be quantified are discussed in three papers: Nelson et al. (2006) 
Fig. 1. The MA Conceptual Framework. Source: MA (2003).

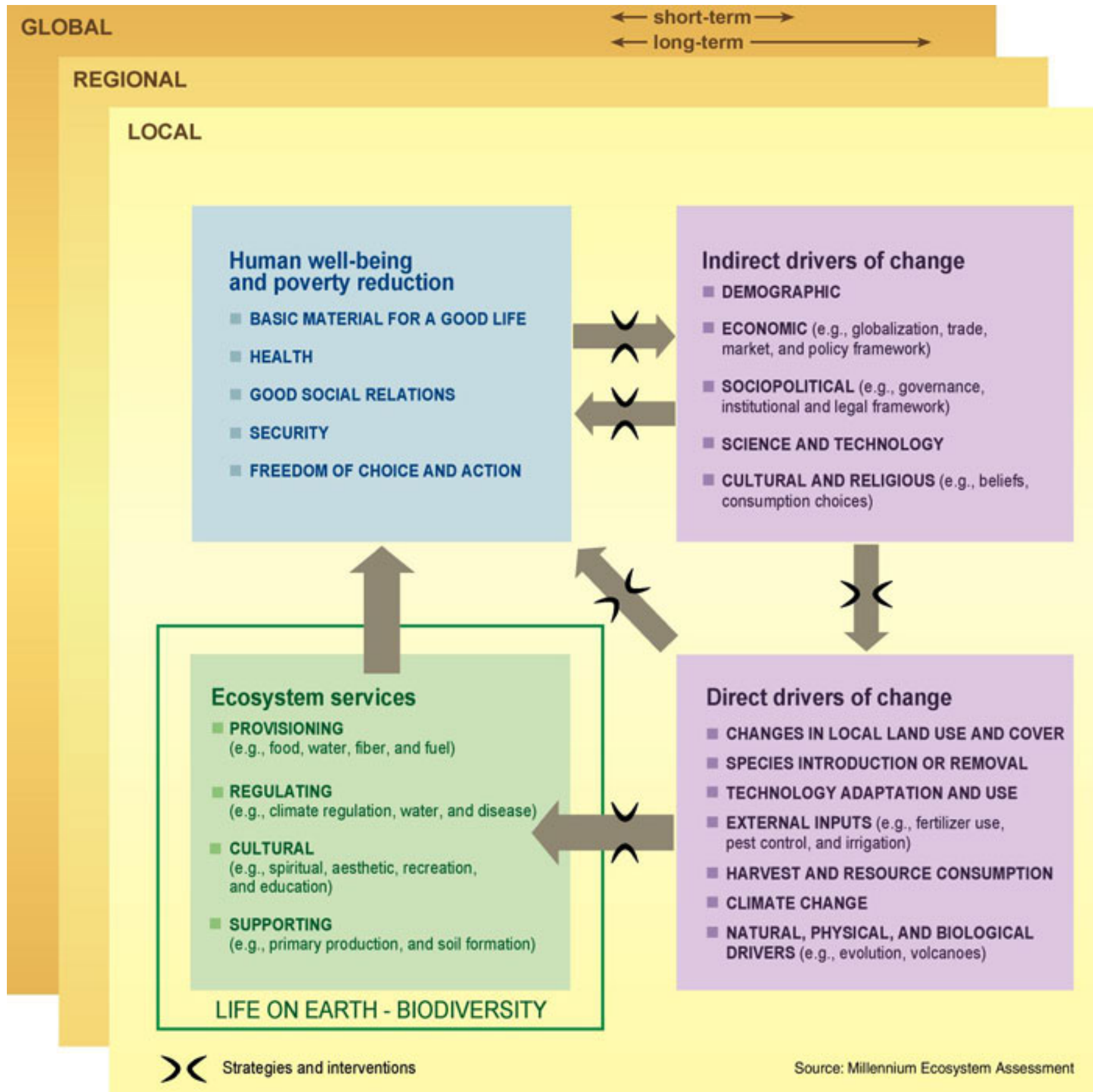

Copyright (C) 2005 World Resources Institute. Reproduced by permission of World Resources Institute, Washington, D.C. 
summarize the drivers of change that were used in quantification; Alcamo et al. (2006) developed projections of key provisioning ecosystem services, such as food, fresh water, and forest products; and van Vuuren et al. (2006) developed quantitative projections of biodiversity change, focusing on species diversity. Collectively, these three papers present key quantitative findings of the MA Scenarios Working Group. We close the Special Feature with two papers that address cross-cutting outcomes of the qualitative storylines and the quantitative analyses. Essentially, all environmental decisions represent tradeoffs among ecosystem services. Some key tradeoffs in the scenarios are addressed by Rodriguez et al. (2006). The MA also explored the connections of ecosystem services to human well-being. Implications of the scenarios for human well-being are addressed by Butler et al. (2006).

This Special Feature was written to provide a synthetic overview of the MA Scenarios in an opensource format widely available to educators, decision makers, and the technical community. The synthesis presented in these papers summarizes selected lessons from the MA Scenarios, but does not provide an exhaustive account of the findings of the Scenarios Working Group. For a complete account, readers are referred to the underlying documents (see reference lists of these papers and http://www.MAweb.org).

Responses to this article can be read online at: http://www.ecologyandsociety.org/voll1/iss2/art32/responses/

\section{Acknowledgments:}

We are grateful for the generous contributions of many experts to the MA scenarios. We especially thank Monika Zurek and Prabhu Pingali for their many contributions to the MA scenarios. Veronique Plocq-Fichelet of SCOPE provided crucial advice, assistance, and support to the Scenarios Working Group throughout the project. This work was supported by the MA, the Scientific Committee on Problems of the Environment, the University of Wisconsin-Madison Center for Limnology, and the Winslow Foundation.

\section{LITERATURE CITED}

Alcamo, J., D. van Vuuren, C. Ringler, W. Cramer, T. Masui, J. Alder, and K. Schulze. 2005. Changes in nature's balance sheet: model-based estimates of future worldwide ecosystem services. Ecology and Society 10(2):19. [online] URL: www .ecologyandsociety.org/vol10/iss2/art19/.

Butler, C. D., and W. Oluoch-Kosura. 2006. Linking future ecosystem services and future human well-being. Ecology and Society 11(1): 30. [online] URL: http://www.ecologyandsociety.org/vol11/iss1/ art30/.

Carpenter, S. R., E. M. Bennett, and G. D. Peterson. 2006. Scenarios for ecosystem services: an overview. Ecology and Society 11(1): 29. [online] URL: http://www.ecologyandsociety.org/vol11/ iss1/art29/.

Cork, S. J., G. D. Peterson, E. M. Bennett, G. Petschel-Held, and M. Zurek. 2006. Synthesis of the storylines. Ecology and Society 11(2): 11. [online] URL: http://www.ecologyandsociety.org/vol11/ iss2/art11/.

Millennium Ecosystem Assessment (MA). 2003. Ecosystems and their services. Chapter 2 in Ecosystems and human well-being: a frameworkfor assessment. Island Press, Washington, D.C., USA.

Millennium Ecosystem Assessment (MA). 2005a. Ecosystems and human well-being: multiscale assessments. Island Press, Washington, D.C., USA.

Millennium Ecosystem Assessment (MA). 2005b. Ecosystems and human well-being: current state and trends. Island Press, Washington, D.C., USA.

Millennium Ecosystem Assessment (MA). 2005c. Ecosystems and human well-being: scenarios. Island Press, Washington, D.C., USA.

Millennium Ecosystem Assessment (MA). 2005d. Ecosystems and human well-being: policy responses. Island Press, Washington, D.C., USA.

Nelson, G. C., E. Bennett, A. A. Berhe, K. Cassman, R. DeFries, T. Dietz, A. Dobermann, A. Dobson, A. Janetos, M. Levy, D. Marco, N. Nakicenovic, B. O'Neill, R. Norgaard, G. Petschel-Held, D. Ojima, P. Pingali, R. Watson, and M. Zurek. 2006. Anthropogenic drivers of 
ecosystem change: an overview. Ecology and Society 11(2): 29. [online] URL: http://www.ecolog yandsociety.org/vol11/iss2/art29/.

Rodríguez, J. P., T. D. Beard, Jr., E. M. Bennett, G. S. Cumming, S. Cork, J. Agard, A. P. Dobson, and G. D. Peterson. 2006. Trade-offs across space, time, and ecosystem services. Ecology and Society 11(1): 28. [online] URL: http://www.ecologyandso ciety.org/vol11/iss1/art28/.

Van Vuuren, D. P., O. E. Sala, and H. M. Pereira. 2006. The future of vascular plant diversity under four global scenarios. Ecology and Society 11(2): 25. [online] URL: http://www.ecologyandsociety.org/ vol11/iss2/art25/. 